\title{
Alkenone surface hydrographic changes of the subarctic Northwestern Pacific since the last glacial: proxy limitations and implications of non-thermal environmental influences
}

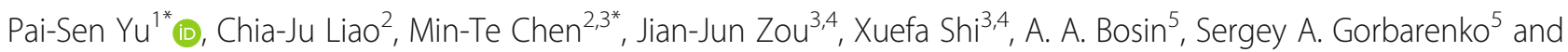
Yusuke Yokoyama ${ }^{6,7,8}$

\begin{abstract}
We investigated an alkenone-based sea surface temperature (SST) and the hydrographic change records of the subarctic Northwestern (NW) Pacific from the last glacial to interglacial. The core we investigated is a piston core (LV 63-41-2, 52.56 N, $160.00^{\circ} \mathrm{E}$; water depth $1924 \mathrm{~m}$ ) retrieved from the southern offshore east coast of the Kamchatka Peninsula, which is a location of high sedimentation rate, with highly dynamic interactions with the cold/warm water masses of the Bering Sea/the NW Pacific. Based on our alkenone analysis with a previously wellestablished chronology of the core, we found high glacial $C_{37: 4}$ contents suggesting larger freshwater influences prior to the last deglacial in approximately $27-16 \mathrm{ka}$ BP. The most significant features of what we found are alkenone indicative of "warming" intervals with minimum alkenone productions that occurred prior to the stadial Heinrich event 1 and the Younger Dryas. In contrast, for the interval corresponding to the Bølling-Allerød period, our alkenone analysis shows relatively "colder" but maximum alkenone productions. We conclude that this particular subarctic alkenone SST proxy record is mainly masked by non-thermal environmental influences, such as strong shifts of timing and duration of the sea ice retreat and/or salinity changes in surface water at this site, which could cause changes in water stratification that affect nutrient supplies of the upper ocean that modulate growth durations of phytoplankton/coccolithophore productions. Our studies suggest that this subarctic alkenone "SST" proxy record is indicative of the changes of seasonality that control the timing and duration of the blooming seasons of coccolithophores. The alkenone "SST" proxy is also dominantly driven by water stratification effects that, instead of SSTs, reflect most likely a combination of the following local to regional climate and ocean current patterns: (1) the amount of meltwater inputs from high mountain glaciers at Kamchatka; (2) less saline, nutrient-rich Alaskan Stream waters from the Cordilleran Ice Sheet in the Gulf of Alaska; (3) downwelling waters associated with (Continued on next page)
\end{abstract}

\footnotetext{
* Correspondence: menardii@mail2000.com.tw; mtchen@mail.ntou.edu.tw

${ }^{1}$ Taiwan Ocean Research Institute, National Applied Research Laboratories, Kaohsiung 80143, Taiwan

${ }^{2}$ Institute of Earth Sciences \& Center of Excellence for the Oceans \& Center of Excellence for Ocean Engineering, National Taiwan Ocean University,

Keelung 20224, Taiwan

Full list of author information is available at the end of the article
}

\section{Springer Open}

(c) The Author(s). 2020 Open Access This article is licensed under a Creative Commons Attribution 4.0 International License, which permits use, sharing, adaptation, distribution and reproduction in any medium or format, as long as you give appropriate credit to the original author(s) and the source, provide a link to the Creative Commons licence, and indicate if changes were made. The images or other third party material in this article are included in the article's Creative Commons licence, unless indicated otherwise in a credit line to the material. If material is not included in the article's Creative Commons licence and your intended use is not permitted by statutory regulation or exceeds the permitted use, you will need to obtain permission directly from the copyright holder. To view a copy of this licence, visit http://creativecommons.org/licenses/by/4.0/. 
(Continued from previous page)

the interactions between the southward Eastern Kamchatka Current and the spinning-up of the North Pacific Subarctic Gyre; and (4) the strength of the Kuroshio Current since the last glacial.

Keywords: Last glacial, Stratification, Alkenone, Sea surface temperature, Northwestern Pacific, Subarctic

\section{Introduction}

The Bering Sea, one of the marginal seas in the Northwestern (NW) Pacific, is a dynamic area to global climate changes. The hydrographic system in the Bering Sea is dominated by the cool water mass from the Arctic Ocean and warm water mass from the northeast Pacific. The Eastern Kamchatka Current (EKC), the major surface current in the west blank of the Bering Sea, tightly links with the Bering Sea and the northeastern Pacific circulations (Woodgate et al. 2005; Stabeno et al. 2005; Panteleev et al. 2006) (Fig. 1). In the winter season, the strong Aleutian Low and accompanying southwesterly winds drive the EKC, greater extension of sea ice formation and cooling of surface waters from the Bering Sea along the offshore of eastern Kamchatka Peninsula. The southward EKC, which is together with the Alaskan Stream (AS) and a branch of the Northwest Pacific Subarctic Gyre (NPSG), feeds into the Oyashio Current (OC) in the Subarctic NW Pacific. The OC reaches its southernmost position with maximum strength in the winter, in contrast to the stronger intensity of the subtropical Kuroshio Current during the summer season. The modern winter surface circulation pattern in the subarctic NW Pacific could be regarded as an analog in the changes of the glacial oceanic circulation.

The paleoceanographic climate changes of the Bering Sea and the subarctic NW Pacific over a millennial time scale are largely determined by changes in sea ice, surface circulation, and their interactions and feedbacks (Gorbarenko 1996; Katsuki and Takahashi 2005; Max et al. 2012; Méheust et al. 2016). The mechanisms that link the climate, sea ice extent, surface ocean condition, and associated temperature and productivity in the upper ocean of the Bering Sea and the subarctic NW Pacific are often hard to disentangle due to the poor preservation of carbonates, which makes it difficult to use foraminifer-based proxies (i.e., $\mathrm{Mg} / \mathrm{Ca}$, oxygen isotopes) extracting the precise hydrographic estimates with oxygen isotope stratigraphy. Previous investigations have been able to provide several alkenone proxy-based, accelerator mass spectrometric (AMS) ${ }^{14} \mathrm{C}$-dated scenarios for interpreting such mechanisms largely driven by sea ice changes of the subarctic NW Pacific from the last glacial (Ternois et al. 2000; Harada et al. 2004; Seki et al. 2004a; Caissie et al. 2010; Max et al. 2012; Schlung et al. 2013; Gorbarenko et al. 2017). During the Heinrich event 1 (HE 1) and Younger Dryas (YD), the seasonal sea ice has increased from the east toward the NW Pacific and retreated to the east for the Bølling-Allerød (B/A) interstadial and early Holocene (Méheust et al. 2016, 2018). Such cases happen today when the maximum sea ice extent is not adjacent to the NW Pacific (Zhang et al. 2010). However, these alkenone proxybased results in the Bering Sea and the subarctic NW

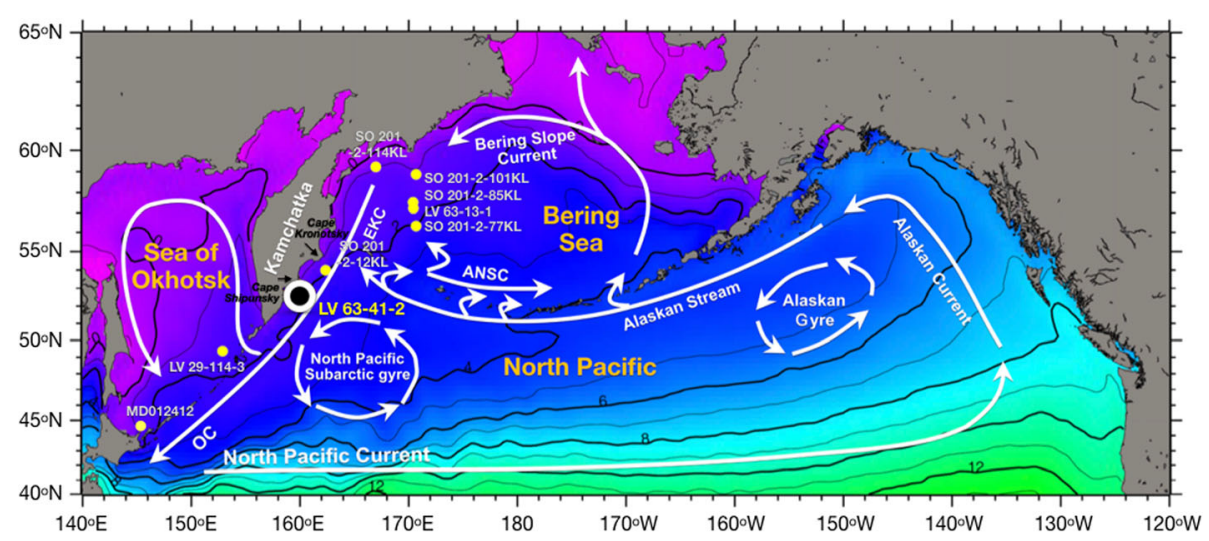

Fig. 1 Map of site locations of the subarctic NW Pacific used in this study. A series of sediment cores along the western blank of Bering Sea, off Kamchatka, and the Okhotsk Sea are used for extracting last glacial alkenone temperature variability of the subarctic NW Pacific. Modern annual mean SSTs in the Northern Pacific are shown with contours using oceanographic data from AVHRR for the 1982-2014 period (Banzon et al. 2016). Core LV 63-41-2 $\left(52.56^{\circ} \mathrm{N}, 160.00^{\circ} \mathrm{E}\right.$; circled bullet symbol) was retrieved at a water depth of $1924 \mathrm{~m}$ from the continental slope off Kamchatka. Core sites of these published alkenone SST records (Seki et al. 2004b; Max et al. 2012) are marked by yellow circle symbols. Surface circulation patterns of the Northern Pacific are abbreviated as follows: EKC, East Kamchatka Current; OC, Oyashio Current; ANSC, Aleutian North Slope Current 
Pacific sediments existed controversial. While some areas illustrate abnormally warm with low alkenone productivity in the cold period (Ishiwatari et al. 2001; Seki et al. 2004b, 2007; Harada et al. 2006), others suggested that it remains under cold conditions (Max et al. 2012; Meyer et al. 2016). Questions regarding this climate abnormality in cold episodes include why alkenone changes in these archives may result in such abnormalities and what reason was responsible for these low alkenone concentrations at high latitudes. The complications of the Bering Sea and the subarctic NW Pacific current patterns with the high seasonality are related to changes in nutrient supplies, ocean salinity, and freshwater inputs from melting sea ice or mountain glaciers. More investigations are needed to bring in-depth understanding on the uses of the alkenone proxies in high-latitude oceans (Rosell-Melé 1998; Sikes and Sicre 2002; Seki et al. 2004b, 2005; Harada et al. 2006; Popp et al. 2006; Caissie et al. 2010; Max et al. 2012).

Apart from what we have from core LV 63-41-2 (Gorbarenko et al. 2017, 2019), which was located in the Bering Sea and the subarctic NW Pacific (Fig. 1), here we present new results of the alkenone sea surface temperature (SST) analysis of LV 63-41-2. Though many proxies measured from the core have been well-presented, this study focuses on (1) presenting alkenone SSTs, $C_{37}$ alkenone concentration, and $\mathrm{C}_{37: 4}$ records based on a well-established age model of the core (Gorbarenko et al. 2017, 2019); (2) investigating the magnitude and patterns of surface ocean conditions and upper ocean stratification off Kamchatka since the last glacial by interpreting the alkenone proxies and, more importantly, their limitations; and (3) advancing our understanding on any plausible mechanisms of climate, sea ice, SST variations, and surface circulations among the subarctic NW Pacific from the last glacial by integrating published alkenone records of a more regional scale.

\section{Oceanographic settings}

The core LV 63-41-2 $\left(52.56^{\circ} \mathrm{N}, 160.00^{\circ} \mathrm{E}\right)$ was recovered in 2013 by the Russian R/V Akademik M.A. Lavrentyev during the Chinese-Russian Joint expedition (Fig. 1). The $467 \mathrm{~cm}$ long core was retrieved from a location at the continental slope off the Kamchatka Peninsula at a water depth of $1924 \mathrm{~m}$, where there is a highly dynamic oceanic front between the cold water mass from the Bering Sea and the warm water mass from the NW Pacific. Numerous investigations have pointed out coccolithophore blooms occurring mainly in early spring and fall at the Bering Sea and the adjacent subarctic Pacific Ocean (Takahashi et al. 2002; Harada et al. 2003; Seki et al. 2004b, 2007). The EKC from the Bering Sea and the AS, which is one of the large-scale currents in the subarctic Northern Pacific, brings relatively cold/ fresh water to the south and along with the AS flows southeastwardly along the offshore of the eastern Kamchatka Peninsula and is one of the major components of the OC (Favorite et al. 1976; Stabeno et al. 1999). The NPSG interacts with the EKC/AS/OC and, in contrast, brings relatively warm/downwelling water to the eastern margins of the Kamchatka Peninsula by Ekman transports. During the wintertime, the Siberian High/Aleutian Low system plays a crucial role in the sea ice cover and the intensity of winter. An extension of sea ice off the Kamchatka enforces the EKC pathway to migrate far from the Kamchatka Peninsula (Zhang et al. 2010). The site of core LV 63-41-2, located at the southwesterly position of the modern EKC pathway, receives most of the terrestrial materials (i.e., ice-rafted debris (IRD), higher magnetic susceptibility values) from the melting of the sea ice via the EKC. In the summer season, the East Asian monsoon conveys more heat and precipitation to high latitudes. Fluctuations in freshwater discharge in the NW subarctic Pacific, in turn, serve a major controlling role for upper ocean stratification and sea ice formation. Therefore, the resulting hydrographic changes in the upper water column at Site LV 63-41-2 would be sourced from (1) freshwater input effects from the melting of sea ice from the EKC, (2) west-flowing waters of the AS, and (3) river runoff from the Kamchatka Peninsula and/or local mountain glacier meltwater inputs to Site LV 63-41-2. Therefore, the sea ice cover, sea ice melting with riverine freshwater inputs, the EKC/AS/OC, and possibly, the NPSG spinning-up, all have important roles on the upper ocean hydrographies at Site LV 63-41-2.

\section{Methods/Experimental Chronologies}

The sediment of core LV 63-41-2 is a high-quality core ideal for paleoceanographic studies, as the core is mainly composed of calcareous ooze with few IRD layers (Gorbarenko et al. 2017). The chronology of the core has been wellestablished based on AMS ${ }^{14} \mathrm{C}$ radiocarbon dates and stable isotope stratigraphy of benthic foraminifera, as well as graphic correlation to non-destructive records (i.e., magnetic properties, color reflectance $\mathrm{b}^{*}$, and X-ray fluorescence core scanning) of a nearby core SO 201-2-12 KL and an absolute dated $\delta^{18} \mathrm{O}$ archives of Hulu/Dongge record (Gorbarenko et al. 2017). In this study, we also present an alternative chronology by adding four more AMS ${ }^{14} \mathrm{C}$ dates that have not been previously used but give new age interpretation in particular for the interval of late $\mathrm{HE} 1$ to $\mathrm{B} / \mathrm{A}$ and back to $4 \mathrm{ka}$ (Table 1; Fig. 2). The purpose of presenting two sets of chronologies is to address any possible uncertainty in interpreting our data due to age models. The age differences in these two chronologies are very small by comparing the 
Table 1 Radiocarbon ages and age controlling points used in the Core LV 63-41-2 chronology

\begin{tabular}{lll}
\hline $\begin{array}{l}\text { Depth } \\
(\mathrm{cm})\end{array}$ & $\begin{array}{l}\text { Age }(\mathrm{ka}) \\
\text { Gorbarenko et al. (2017) }\end{array}$ & $\begin{array}{l}\text { Age }(\mathrm{ka}) \\
\text { This study }\end{array}$ \\
\hline $120^{\mathbf{a}}$ & 9.12 & 9.12 \\
126 & 9.51 & \\
$127.5^{\mathbf{a}}$ & & 9.45 \\
$156^{\mathbf{a}}$ & & 10.6 \\
159 & 11.08 & 11.08 \\
167 & 11.31 & 11.31 \\
234 & 13.08 & 13.08 \\
251 & 13.42 & 13.42 \\
273 & 13.79 & 13.79 \\
$298^{\mathbf{a}}$ & & 14.39 \\
303 & 14.42 & 14.42 \\
$306^{\mathbf{a}}$ & & 14.62 \\
337 & 15.42 & 15.42 \\
348 & 16.16 & 16.16 \\
357 & 16.51 & 16.51 \\
379 & 17.56 & 17.56 \\
393 & 18.12 & 18.12 \\
402 & 18.60 & 18.60 \\
405 & 18.78 & 18.78 \\
423 & 19.25 & 19.25 \\
434 & 19.54 & 19.54 \\
\hline${ }^{a} \mathrm{AmS}$ & & \\
\hline 14 & &
\end{tabular}

timing of millennial-scale climate events. In particular, the timing of major millennial climate intervals such as stadial HE 1, B/A interstadial, and YD is still clearly identified and well-constrained irrespective of two chronologies (Fig. 2).

Continuous time scales between two successive age control points were obtained by linear interpolations. Sedimentation rates calculated by the use of the published age model (Gorbarenko et al. 2017) are approximately $40 \mathrm{~cm} / \mathrm{kyr}$ at average. The samples in the alkenone analysis we presented were from an every $2 \mathrm{~cm}$ interval, corresponding to a time resolution of $\sim 35$ to $\sim$ 135 years (average 80 years) throughout this core. Therefore, these excellent materials could provide highquality, millennial-scale alkenone-based proxy records.

\section{Alkenone concentration and SST estimates}

We sampled the core for the analyses of alkenone biomarkers at every $2 \mathrm{~cm}$ interval and extracted alkenones from $\sim 3 \mathrm{~g}$ of freeze-dried and homogenized sediments following a procedure described by Müller et al. (1998). An internal standard $n-C_{36} \mathrm{H}_{74}$ was added into the extracted fraction F3 (alkenones and alkenoates) prior to injection. The fraction containing alkenones was analyzed with a Hewlett Packard 5890 series N gas chromatograph (GC) with a cool on-column injection, electron pressure control system, and flame ionization detector. The GC is equipped with a $60 \mathrm{~m}$ column (Chrompack CP-Sil5 CB, $0.25 \mathrm{~mm} \times 0.25 \mu \mathrm{m}$ ). Samples were then dissolved in a hexane solution. The flow velocity of a carrier gas Helium was maintained at $30 \mathrm{~cm} / \mathrm{s}$. For the analysis of the $\mathrm{F} 3$ fraction, the oven temperature was programmed to reach $70-290{ }^{\circ} \mathrm{C}$ at $20{ }^{\circ} \mathrm{C} / \mathrm{min}, 290-310{ }^{\circ} \mathrm{C}$ at a speed of $0.5{ }^{\circ} \mathrm{C} / \mathrm{min}$, and then isothermal at $310{ }^{\circ} \mathrm{C}$ maintained for more than $30 \mathrm{~min}$. Quantification of the alkenones was further identified by comparing the retention times with the synthetic standards (adopted by Prof. M. Yamamoto at Hokkaido University, Japan). The alkenone unsaturation index $\mathrm{U}^{\mathrm{k}^{\prime}}{ }_{37}$ and its SST estimate were calculated using a global core-top calibration $\left(60^{\circ} \mathrm{N}-60^{\circ} \mathrm{S}\right.$; $\mathrm{U}^{\mathrm{k}^{\prime}}{ }_{37}$ $=0.033 \times \mathrm{T}+0.044)$ developed by Müller et al. (1998). The mean standard error of the estimated alkenone-SST is approximately $1{ }^{\circ} \mathrm{C}$ (Conte et al. 2006). The alkenone-derived temperature estimate is identical to those based on Emiliania huxleyi culturebased calibrations from Prahl et al. $\left(1988 ; \mathrm{U}^{\mathrm{k}^{\prime}}{ }_{37}=\right.$ $0.034 \times \mathrm{T}+0.039)$. Meanwhile, in order to understand the applicability of $U^{\mathrm{k}}{ }_{37}$ and $\mathrm{U}^{\mathrm{k}^{\prime}}{ }_{37}$ calibrations on the subarctic NW Pacific core LV 63-41-2, here, all calculated $U^{k}{ }_{37}$ values were also converted into SST estimates by using calibrations from the continuous culture of E. huxleyi (Prahl et al. 1988; $\mathrm{U}_{37}^{\mathrm{K}}=0.040 \times$ $\mathrm{T}-0.104)$. The original $\mathrm{U}_{37}^{\mathrm{k}}$ index, which incorporates the $\mathrm{C}_{37: 4}$ compound, gives some benefits compared with $\mathrm{U}^{\mathrm{k}^{\prime}}{ }_{37}$. More $\mathrm{C}_{37: 4}$ contents have been found from environments of low temperatures (Rosell-Melé et al. 1994) and/or low salinity waters (Harada et al. 2003). Higher $C_{37: 4}$ values of LV 63-41-2 would reflect sources of freshwater inputs that could be mainly from sea ice melting and increased supply of freshwater/ river runoff from the melting of mountain glaciers at the Kamchatka Peninsula. Therefore, the calculated $\mathrm{C}_{37}$ alkenone concentration and $\mathrm{C}_{37: 4}$ contents are used in this study as proxies for alkenone productivity and freshwater inputs, respectively.

\section{Results}

Alkenone temperatures and concentrations

We have generated millennial-scale alkenone-derived temperature and its related biomarker signals, including $\mathrm{C}_{37}$ alkenone productivity and $\mathrm{C}_{37: 4}$-based estimates on relative changes in the freshwater contribution, based on samples from core LV 63-41-2. The alkenone SST estimates at core-top samples are in good agreement with modern summer SST $\left(9.3{ }^{\circ} \mathrm{C}\right.$ in July; Locarnini et al. 2010). The overall alkenone SSTs range very largely from 1.8 to $17.9{ }^{\circ} \mathrm{C}$ (with a mean of $8.8^{\circ} \mathrm{C} \pm 3.1{ }^{\circ} \mathrm{C}$ ) and 


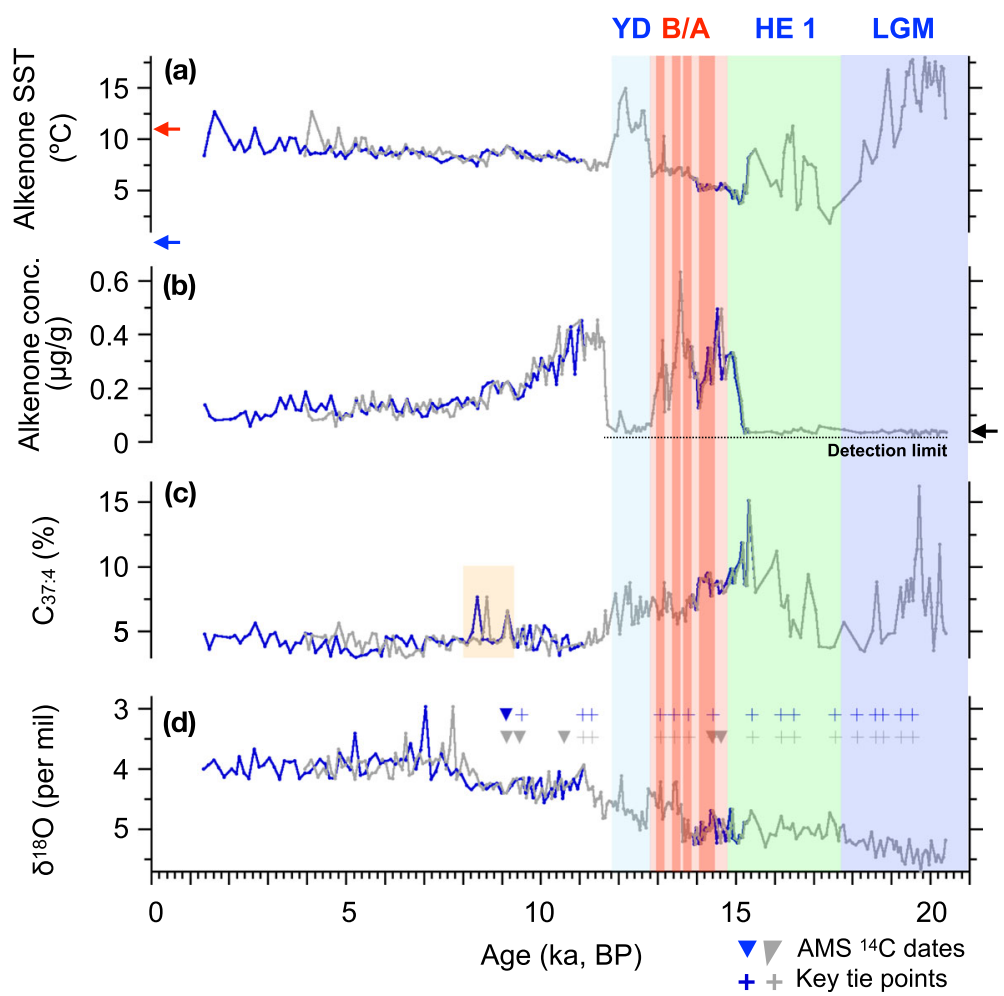

Fig. 2 Downcore LV 63-41-2 alkenone proxy-based estimates since the last glacial. a $\cup^{k^{\prime}}{ }_{37-S S T}$, b alkenone concentration (or total $C_{37}$ ), and $\mathbf{c} C_{37: 4}$ freshwater index, all are plotted against age and compared to $\mathbf{d}$ published downcore $\delta^{18} \mathrm{O}$ stratigraphy and chronology (Gorbarenko et al. 2017; this study). Records applied in different chronologies from Gorbarenko et al. (2017, 2019), and this study is indicated by blue and gray, respectively. Age differences between those two chronologies are minor on late HE 1-early B/A and late-middle Holocene, except for late Holocene. Shaded intervals indicate LGM, stadial HE 1, B/A (sub)-interstadials, and YD. Modern summer and winter SSTs are indicated, respectively, by red and blue arrows on a. Also, 9-8 ka events mentioned in this text are also shaded in $\mathbf{c}$. Prior to HE 1, our mean alkenone concentration $(0.038 \pm 0.008 \mu \mathrm{g} / \mathrm{g})$ and detection limit of measuring the alkenone concentration $(0.02 \mu \mathrm{g} / \mathrm{g}$; Seki et al. 2004a) are indicated, respectively, by a black arrow and dashed line in $\mathbf{b}$

show a large cooling of approximately $16{ }^{\circ} \mathrm{C}$ from the last glacial maximum (LGM) to the onset of stadial HE 1 (Fig. 2a). It is worth noting that LGM SSTs $\left(\sim 15{ }^{\circ} \mathrm{C}\right.$ on average; $19-23 \mathrm{ka})$ are warmer than the present $(\sim 8.4$ ${ }^{\circ} \mathrm{C}$ in the core-top sample). Besides, large millennialscale SST fluctuations of approximately $5-7{ }^{\circ} \mathrm{C}$, particularly in the LGM-HE 1 interval, are observed, which is considered moderate when compared with the modern SST seasonality of approximately $10-11{ }^{\circ} \mathrm{C}$ at this site (Locarnini et al. 2010). The millennial-scale SST fluctuations are muted in the alkenone concentrations high and warming intervals $\mathrm{B} / \mathrm{A}$ and Holocene. Furthermore, a rising of alkenone SSTs from the early Holocene toward the present ranges from $\sim 7.5$ to $10{ }^{\circ} \mathrm{C}$, which is close to the modern observed SST from June to October (Locarnini et al. 2010).

Changes in downcore $\mathrm{C}_{37}$ alkenone contents exhibit greater values with more significant fluctuations (> $0.2 \mu \mathrm{g} / \mathrm{g})$ during the $\mathrm{B} / \mathrm{A}$ interstadial $(\sim 0.06-0.63 \mu \mathrm{g} / \mathrm{g})$ and early Holocene $(\sim 0.15-0.40 \mu \mathrm{g} / \mathrm{g})$ compared with other time intervals (Fig. 2b). Noticeable alkenone concentration lows $(\sim 0.038-0.054 \mu \mathrm{g} / \mathrm{g})$ are also observed prior to $15 \mathrm{ka}$ (LGM) and from 12.8 to $11.8 \mathrm{ka}$ (YD). Noticeable millennial-scale alkenone concentration highs that may link with the changes of alkenone productivity in the B/A are clearly observed here. The millennial alkenone concentration highs are consistent with three "sub-interstadials" productivity highs based on other proxies measured from the same core (Gorbarenko et al. 2017), suggesting that the productivity changes in the $\mathrm{B} / \mathrm{A}$ are proxy independent. Our alkenone concentrations reached maxima abruptly and maintained for approximately $1-2 \mathrm{kyr}$ by the end of the YD, and after the maxima, decreased gradually toward a minimum value of approximately below $0.1 \mu \mathrm{g} / \mathrm{g}$ from the early to late Holocene, with two steps of slightly back to higher values at approximately 9-8 ka (within the uncertainties of our age models).

The apparent alkenone-based "warming" at most parts of the LGM, HE 1, and YD in our core is inconsistent with and even at opposite to previously reported values for the global LGM and millennial-scale cooling 
scenarios. We further observed that the timing and duration of apparent warming coincided with the intervals of very low alkenone concentrations $\left(\mathrm{C}_{37}\right.$ alkenones) at the YD period $(\sim 12.8-11.8 \mathrm{ka})$ and prior to $15 \mathrm{ka}$ (Fig. 2a). The alkenone estimated warming with very low concentrations is not likely due to the uncertainties of age models (Gorbarenko et al. 2017). Rather than casting doubt on the accuracy of the chronology and alkenone analysis, here we interpret that those apparent warming would probably be much relevant to various nonthermal effects on the alkenone proxies such as the shifting of the optimum growing seasons of coccolithophorids, upper ocean hydrographic and circulation pattern changes, and freshwater effects from sea ice/ mountain glacier melting (see the "Discussion" section).

\section{Alkenone $\mathrm{C}_{37: 4}$}

Our measured $C_{37: 4}$ contents at core LV 63-41-2 exhibit large variations (Fig. 2c). The $\mathrm{C}_{37: 4}$ contents fluctuate with relatively maximum values at intervals of late LGM and of HE 1 to YD, whereas its minima (<5\%) mostly appear throughout the whole Holocene with the exception of two abrupt spikes (> 7\%) at approximately $9.0 \mathrm{ka}$ and 8.6-8.2 ka. We further observed high $C_{37: 4}$ contents exist in not only the $\mathrm{B} / \mathrm{A}$ but also the stadial HE 1/YD. Notably, the high $\mathrm{C}_{37: 4}$ content starts from the onset of stadial HE 1 and reaches its relatively high value of approximately $10 \%$ at the end of HE 1 . At the B/A interstadial, the $\mathrm{C}_{37: 4}$ contents show millennial or higher frequency changes and, interestingly, sometimes antiphased with alkenone concentrations. The $\mathrm{C}_{37: 4}$ contents have gradually decreased from the mid-B/A and then persists relatively high frequent variations throughout the YD. The $\mathrm{C}_{37: 4}$ contents persist low but exhibit two short-lived higher values at approximately $9-8 \mathrm{ka}$ (within the uncertainties of our age models) throughout the Holocene.

\section{Discussion}

\section{Glacial alkenone "warming": proxy limitations}

Prior to stadial HE 1 and YD, the anomalous surface warming shown in our alkenone proxy estimates coincided with the lowest alkenone productions at Site LV 63-41-2 (Fig. 2a, b). The glacial surface warming is not only confined to the southwestern position off Kamchatka, as reported from this site but also presented in semi-closed marginal seas around the NW Pacific and northeastern Pacific (Barron et al. 2003; Max et al. 2012). Marine sedimentary archives from the Japan Sea and Okhotsk Sea are also characterized by such anomalous warmer conditions during glacial periods (Seki et al. 2004b). One question regarding this climate "abnormality" in the last glacial is that any non-thermal factors have been responsible for warm bias associated with low alkenone productions. Our LV 63-41-2 LGM SST ( 15 ${ }^{\circ} \mathrm{C}$ in average; $\left.19-23 \mathrm{ka}\right)$ is $\sim 6-7{ }^{\circ} \mathrm{C}$ warmer than the Holocene SST $\left(\sim 8.6{ }^{\circ} \mathrm{C}\right.$ in average), showing an unusual sea surface warming off Kamchatka that is inconsistent with the global LGM scenario (CLIMAP 1981; MARGO Project Members 2009). Though the gradients of $\mathrm{U}^{\mathrm{k}^{\prime}}{ }_{37^{-}}$ SST calibrations are decreased at high- and lowtemperature extremes (e.g., Prahl and Wakeham 1987; Müller et al. 1998), we considered that this would not make our SST estimates drift to such anomalous warming for the LV 63-41-2 samples from the LGM and glacial periods. We noted that the alkenone productivity is temperature-dependent in that the high-latitude samples located around the margins of sea ice covers have alkenone concentration lows (Seki et al. 2004b; Max et al. 2012). If the alkenone concentrations are close to the detection limit of measuring the alkenone unsaturation ratio, the SST estimates would be in large errors. Very low alkenone concentrations with no SST estimations prior to $15 \mathrm{ka}$ have been reported in the NW Pacific (Ternois et al. 2000; Barron et al. 2003; Caissie et al. 2010; Seki et al. 2004a; Max et al. 2012). Moreover, Seki et al. (2004a) reported that prior to $15 \mathrm{ka}$, alkenone SST estimates with low alkenone concentrations down to approximately $0.02 \mu \mathrm{g} / \mathrm{g}$ may have brought with it large uncertainties. In this study, LV 63-41-2 sediment samples have been processed using the resemble procedures and the same type of GC machine as well as Seki et al. (2004a). In order to clarify each alkenone, we processed a threshold of the integration height of the GC-FID chromatogram as a similar signal-to-noise ratio in our alkenone analyses. We also observed that our alkenone concentration lows $(0.038 \pm 0.008 \mu \mathrm{g} / \mathrm{g}$; Fig. $2 \mathrm{~b})$ prior to HE 1 are twice that of the detection limit of measuring the alkenone unsaturation ratio and the results from Seki et al. (2004a). Therefore, the very low alkenone concentrations reported here are not due to any GC instrumental issues or analytical errors.

The LV 63-41-2 alkenone concentrations in the interval of the LGM to HE 1 bring great uncertainties in our alkenone SST analysis. Though large uncertainties of our alkenone SST estimates occur during very low concentration interval, large millennial-scale SST fluctuations of approximately $5-7{ }^{\circ} \mathrm{C}$, particularly in the LGMHE 1 interval, are observed. The millennial-scale SST fluctuations at LV 63-41-2 are muted in the alkenone concentrations high and warming intervals $\mathrm{B} / \mathrm{A}$ and Holocene (Fig. 2a, b). Though the millennial-scale patterns of our alkenone SST estimates could be highly associated with large uncertainties in our analysis for the low concentration samples, the long-term warming trend from the onset of HE 1 to the Holocene shown in our record is for predominating temperature driven. Furthermore, in comparing the alkenone identification 
in our GC analyses on one low concentration sample (LGM) and one high concentration (B/A) with retention times and an internal standard (Fig. 3a, b), we found that the cold indicator $\mathrm{C}_{37: 3}$ content in the LGM sample reaches a minimum (peak area of 10.4 at LGM example and 127.9 at $\mathrm{B} / \mathrm{A}$ example). The mean peak area of the $\mathrm{C}_{37: 3}$ alkenone at LGM is at least 10 times as small as those at the $\mathrm{B} / \mathrm{A}$. The concentration of the two alkenones determined by obtaining the small peak area would bias $\mathrm{U}^{\mathrm{k}^{\prime}}{ }_{37}$ higher and in turn give apparently warmer SST estimation.

The changes of the timing and duration of the coccolithophore blooms in annual cycles would bias alkenone SST estimates. Investigations have been conducted to observe coccolithophore blooms occurring mainly in early spring and fall at the Bering Sea and the adjacent subarctic Pacific Ocean (Takahashi et al. 2002; Harada et al. 2003; Seki et al. 2004b, 2007). During the LGM, spring sea ice cover would have significantly advanced southward and further occupied around the offshore of Kamchatka and the Sea of Okhotsk, as revealed by the $\mathrm{IP}_{25}$ sea ice variability from the NW Pacific (Méheust et al. 2016). Consistent with the results from a previous investigation (Seki et al. 2004b) and new evidence of low alkenone concentrations in LV 63-41-2 during the LGM in this study, we infer that the greater expansion of the spring sea ice cover would restrict light availability and nutrient supply in the upper ocean. The more expanded LGM sea ice cover would have shortened the durations of warm seasons during which phytoplankton/coccolithophores have been growing in the Bering Sea and subarctic NW Pacific. With respect to offshore Kamchatka, we speculate that a shift of the timing and duration on sea ice covers could cause changes in upper
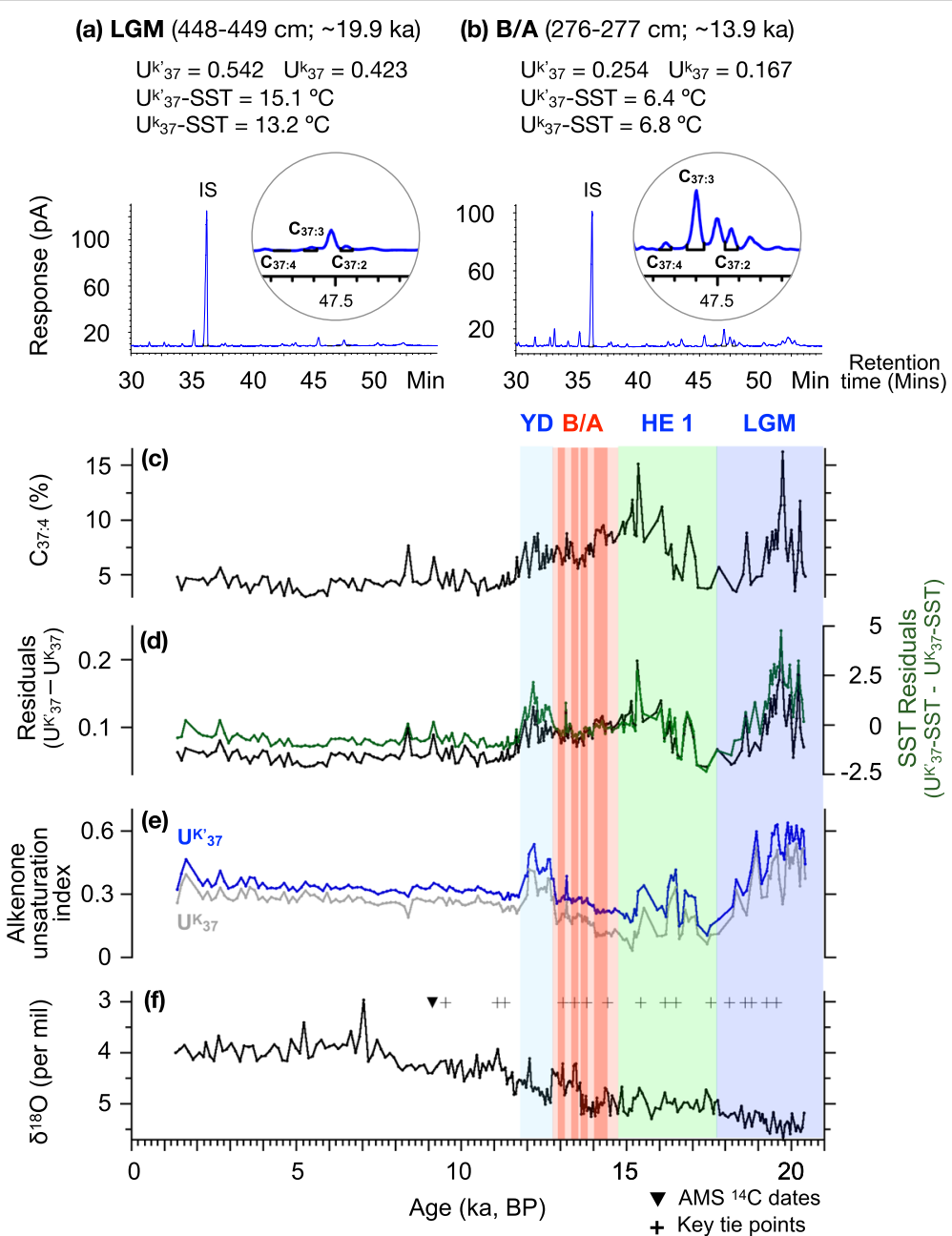

Fig. 3 Example chromatograms of glacial alkenone warming and downcore alkenone-related variations since the last glacial. Representative GCFID chromatograms of alkenone-containing sediment extracts from examples of $\mathbf{a} L G M$ and $\mathbf{b}$ the B/A interstadial are illustrated. Alkenone peak assignation: IS/Internal standard, $C_{37: 4,}, C_{37: 3,} C_{37: 2}$. $\mathbf{c}$ freshwater signals $C_{37: 4,}$ d residuals in alkenone unsaturation index $\left(U^{k^{\prime}}{ }_{37}-U^{k}{ }_{37} ;\right.$ black) and alkenone SSTs (red), and e alkenone unsaturation index $U^{k^{\prime}}{ }_{37}$ (blue) and $U_{37}^{k}$ (gray), all are plotted against age and compared with the $\mathbf{f}$ published downcore $\delta^{18} \mathrm{O}$ stratigraphy (Gorbarenko et al. 2017, 2019). Shaded intervals indicate LGM, stadial HE 1, B/A (sub)-interstadials, and YD 
water stratification and nutrient supply at our studied site. This would also modulate the magnitude of phytoplankton and coccolithophore productions and, therefore, bias our alkenone SST estimates.

As noticeable $\mathrm{C}_{37: 4}$ contents in LV 63-41-2 samples were observed (Fig. 3c), alternatively, we have tested our LV 63-41-2 alkenone SST estimates by calculating $\mathrm{U}^{\mathrm{k}}{ }_{37}$ and $\mathrm{U}^{\mathrm{k}^{\prime}}{ }_{37}$ (Prahl et al. 1988; Müller et al. 1998) and found that the differences between the $\mathrm{U}^{\mathrm{k}^{\prime}}{ }_{37}$ and $\mathrm{U}^{\mathrm{k}}{ }_{37}$ (i.e., $\mathrm{U}^{\mathrm{k}^{\prime}}{ }_{37}-\mathrm{U}^{\mathrm{k}}{ }_{37}$ ) are very small (approximately $0.1-0.2$, corresponding to $2-5{ }^{\circ} \mathrm{C}$ ) (Fig. $3 \mathrm{~d}$, e) that it does not change the pattern of our alkenone SST estimates. These results suggest that our alkenone SST estimation pattern is independent from the uses of either $\mathrm{U}^{\mathrm{k}}{ }_{37}$ or $\mathrm{U}^{\mathrm{k}^{\prime}}$ equations. The existence of noticeable $\mathrm{C}_{37: 4}$ contents in LV 63-41-2 is intriguing (Fig. 3c), possibly revealing the increases of freshwater input since the end of the LGM and through the $\mathrm{B} / \mathrm{A}$ and $\mathrm{YD}$. These high $\mathrm{C}_{37: 4}$ abundances would be possibly relevant to a large amount of melting sea ice and freshwater pulses (Rosell-Melé 1998; Sikes and Sicre 2002; Max et al. 2012; Meyer et al. 2016) from the Bering Sea or off the Kamchatka entering and/ or reaching Site LV 63-41-2. Furthermore, the AS that is characterized by warm and less saline water from the northeast Pacific would be jointly responsible for high $\mathrm{C}_{37: 4}$ contents (Caissie et al. 2010; Meyer et al. 2016; Smirnova et al. 2015; Maier et al. 2018; Gong et al. 2019). Our alkenone-related results, which are consistent with non-alkenone-based proxy data and conceptual models in the northeast Pacific, are support for nonthermal environmental influences off Kamchatka.

The timing of the increase of the LV 63-41-2 $\mathrm{C}_{37: 4}$ contents differs from what has been reported from the Sea of Japan and the Okhotsk Sea, which exhibit no remarkable increases of freshwater supply during the LGM (Seki et al. 2004a). We hypothesize that, based on the modern ocean current pattern of the Bering Sea and subarctic NW Pacific, increased LV 63-41-2 $C_{37: 4}$ contents may have been either brought by more meltwaters from the nearby Kamchatka mountain glacier via the Kamchatka River or by the relatively less saline water of the eastern branch of the EKC from the AS and NPSG waters, which mixed with meltwaters from the Cordilleran Ice Sheet (CIS) in the Gulf of Alaska during the deglaciation. In this scenario, the southward EKC bringing some less saline water mass and/or floating icebergs would directly flow along the offshore of the Eastern Kamchatka Peninsula into the downstream region (south of the Cape Shipunsky, Kamchatka) during from the LGM through the YD.

\section{Implications on hydrographic changes: time-interval scenarios}

Our new alkenone proxy analysis based on the core LV 63-41-2 adds more information on understanding the surface ocean hydrographic changes. Our alkenone analysis not only brings information on temperature evolution but also the changes in various non-thermal environmental influences in the Bering Sea and subarctic NW Pacific over time since the last glacial. In below, we argue the most likely climatic and oceanographic scenarios from the last glacial to the Holocene, with more regional alkenone proxy data sets compiled from the subarctic NW Pacific (the west blank of Bering Sea, off Kamchatka, the Okhotsk Sea) (Max et al. 2012) (Fig. 4) as follows:

\section{The last glacial ( 20-17.8 ka)}

During the last glacial, the EKC, accompanied by icebergs and meltwater, flow along the Kamchatka Peninsula appears to be strengthened and extended further south, as evidenced by the presence of high IRD abundances at the Bering Sea and the offshore Kamchatka (Gorbarenko 1996; Bigg et al. 2008). The higher magnetic susceptibility of LV 63-41-2 also suggests that more terrestrial sediments were carried by the sea ice to the offshore of the Kamchatka Peninsula at this time (Gorbarenko 1996). During the last glacial, the Okhotsk Sea has been mostly sea ice-covered, with less vegetation, as revealed by higher IRD contents and relatively low pollen abundances (Gorbarenko et al. 2019). Furthermore, a study based on $\mathrm{IP}_{25}$, a sea ice indicator, also suggested a greater expansion of the spring sea ice cover around the sea of Okhotsk and off Kamchatka (Méheust et al. 2016, 2018). The presence of a more expanded spring sea ice cover limits the nutrient supply, and the penetration depth of light into the upper ocean, and that, in turn, shortened the growing seasons of coccolithophore productions. A shift of the timing and duration on maximum phytoplankton productivity would bias the alkenone temperature estimates to warmer seasons. It explains the surface "warming" in the Okhotsk Sea (MD012412) (Seki et al. 2004b) and in the southern offshore of the Kamchatka (LV 63-41-2) (Fig. 4). The stability of the upper ocean stratification off Kamchatka during the LGM may have been strengthened due to meltwater inputs from long persistence of spring sea ice cover and the enhanced icebergs-carried EKC. The massive meltwater would decrease the surface water salinity to form a freshwater barrier layer that decreases the air-sea heat exchange as well as the upwelling of nutrients, and both serve as an explanation for the "warming" and low production of alkenone at this time interval.

\section{The HE 1 ( 17.8-14.7 ka)}

Our LV 63-41-2 alkenone SSTs exhibits a gradual warming but large, millennial-to possibly centennial-scale fluctuations $\left(\sim 5-7{ }^{\circ} \mathrm{C}\right)$ since the LGM to HE 1 , though 

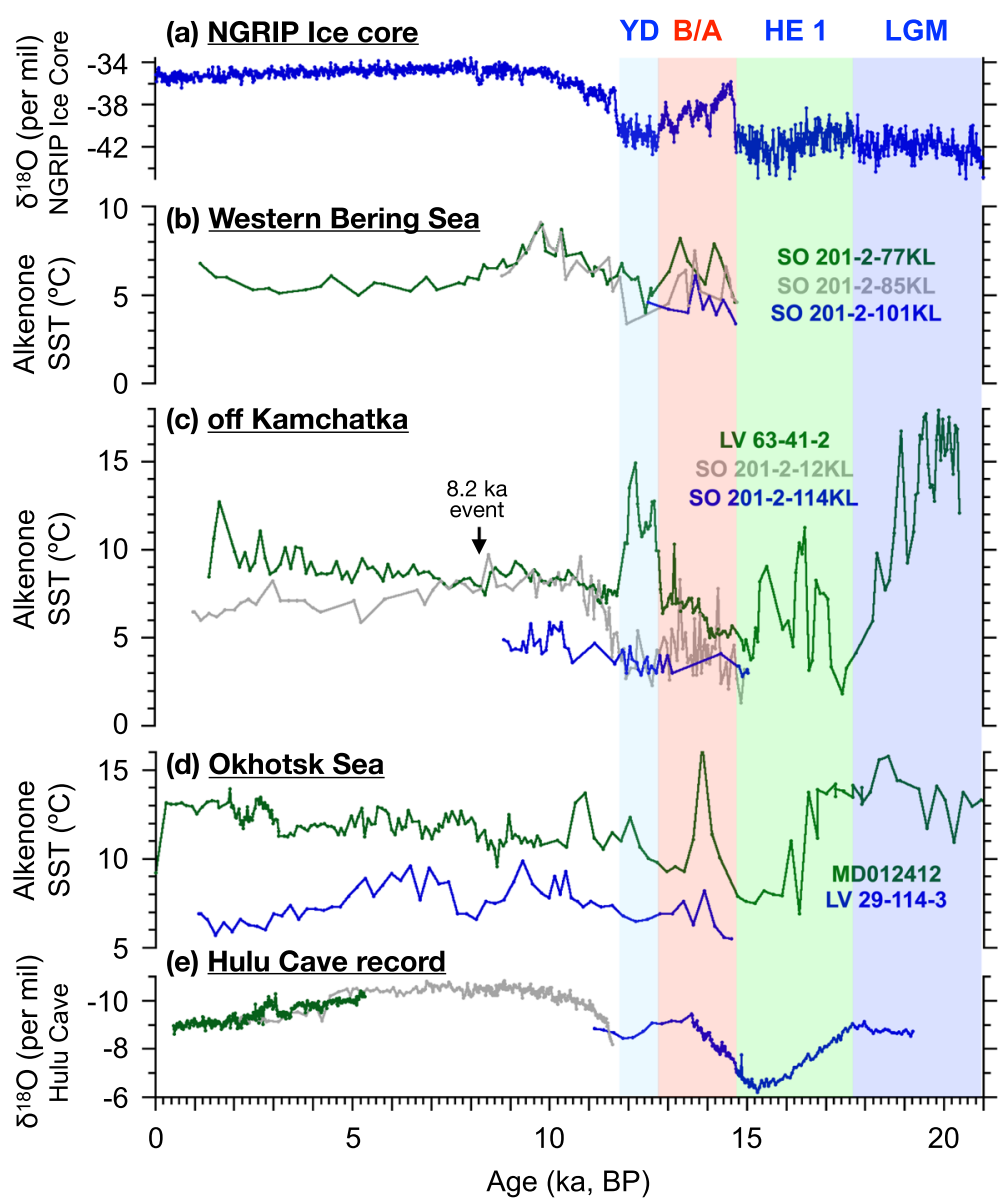

Fig. 4 Last glacial subarctic NW Pacific alkenone-SST changes and its linkage with high-to-low latitude climate variability. a Northern Atlantic climate variability represented by NGRIP ice core $\delta^{18} \mathrm{O}$ sequence (GICC05; North Greenland Ice Core Project members 2004); b western Bering Sea alkenone-SST records: SO 201-2-101 KL, SO 201-2-85KL, and SO 201-2-77KL (Max et al. 2012); c off Kamchatka alkenone-SST records: SO 201-2114KL, SO 201-2-12KL, and LV 63-41-2 (Max et al. 2012; This study); d the Okhotsk Sea alkenone-SST records: LV 29-114-3 and MD012412 (Max et al. 2012); and e East Asian monsoon climate variability represented by the Hulu cave $\delta^{18} \mathrm{O}$ sequence (Wang et al. 2004). Shaded intervals indicate $L G M, H E 1, B / A$, and YD. Arrow shows the 8.2 ka cooling event

the Okhotsk Sea record shows a prolonged "plateau-like" warming till approximately $16.8 \mathrm{ka}$ and then a large cooling $\left(\sim 5{ }^{\circ} \mathrm{C}\right)$ in the later interval of the HE 1 (Fig. 4$)$. It is likely that during the HE 1, the Bering Sea and NW subarctic Pacific were still covered with sea ice year round (Méheust et al. 2016); the rapid changes of our alkenone SSTs and $\mathrm{C}_{37: 4}$ freshwater contents during the HE 1 would suggest a highly dynamic, unstable sea ice system with more frequent meltwater pulses into the sea. Hydrographic reconstructions of subsurface temperatures based on $\mathrm{Mg} / \mathrm{Ca}$, along with $\delta^{18} \mathrm{O}$ on foraminifera Neogloboquadrina pachyderma (L) at a nearby core SO 201-2-12KL, further suggested that cold and fresh conditions would enhance upper ocean stratification during the HE 1 (Riethdorf et al. 2013). Far from the northeast Pacific, several non-alkenone proxy data and conceptual models address that freshwater inputs resulted in an enhanced ocean stratification during the deglacial warming (e.g., Caissie et al. 2010; Meyer et al. 2016; Smirnova et al. 2015; Maier et al. 2018; Gong et al. 2019). These above results of subarctic NW Pacific are coincident with the continental runoff and intensified iceberg calving in the northeastern Pacific, associated with the beginning retreat of continental ice caps during the HE 1 (Gebhardt et al. 2008; Hendy and Cosma 2008; Taylor et al. 2014). During the HE 1 , less saline water would be brought by the AS to the southern offshore of the Kamchatka due to the dynamics of the CIS in the northeast Pacific (Davies et al. 2011; Taylor et al. 2014; Maier et al. 2018). We further speculate that more less saline and warm water had been dynamically transported by the AS and NPSG to the subarctic NW Pacific during stadial HE 1. Moreover, more rapid spinning up of the NPSG would cause coastal downwelling near the southern offshore of the Kamchatka. It could be expected that the LV 63-41-2 would be more influenced by warm water 
from the NPSG (MD012416; Gebhardt et al. 2008). The millennial- to possibly centennial-scale SST fluctuations of LV 63-41-2 during the HE 1 imply highly dynamic interactions between the AS and NPSG. At the end of the HE1, the surface hydrographies in either the offshore of the Kamchatka or the south Okhotsk Sea have switched to warming that coincides with the strengthened Asia summer monsoons (Wang et al. 2004) and boreal high latitude climate (North Greenland Ice Core Project members 2004) (Fig. 4). The surface current pattern in the offshore of the Kamchatka must have been changed dramatically by the end of the HE 1 due to a significant retreat of sea ice covers that favored high alkenone productivity at LV 63-41-2 and higher biogenic opal productivity at SO 201-2-12KL (Méheust et al. 2016).

\section{The $B / A(\sim ~ 14.7-12.8 \mathrm{ka})$}

Our alkenone SSTs during the B/A show a relative "cooling" in contrast to the warming in the Bering Sea and the Okhotsk Sea (Fig. 4). An ice-free condition with higher biogenic productivity has been widespread in the subarctic NW Pacific during the B/A interstadial (Méheust et al. 2016). It is consistent with what has been indicated by the IRD coarse fraction and chlorins (a productivity proxy) measured from the same core (Gorbarenko et al. 2017), as well as with what has been inferred from diatom assemblages and the sea ice cover index $\mathrm{IP}_{25}$ (Méheust et al. 2016, 2018). A similar feature of the deglacial meltwater input in the AS and elevated biogenic productivity from the northeast Pacific after

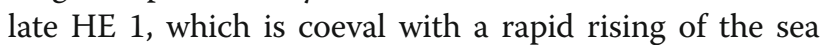
level, is also observed (Gebhardt et al. 2008; Davies et al. 2011; Taylor et al. 2014). The apparent "cooling" shown in our alkenone SST record is likely to be better explained by more prolonged growing seasons of coccolithophores, which have not been living very restrictedly in peak summer as in the last glacial to the HE 1 when sea ice cover has been largely expanded. In this respect, we argue that the apparent "cooling" during the B/A has been also partially biased by the seasonality of coccolithophores growing in the subarctic. As the "cooling" is only observed in our record but not in other records from the Bering Sea (SO 201-2-77KL, -85KL, -101KL) and the Okhotsk Sea (MD012412), we also argue that the local ocean current pattern changes adjacent to the southern offshore of the Kamchatka is responsible for the cooling. For example, the relative cold and nutrientrich EKC water may have been blocked by the more freshwater inputs from melting mountain glacier around Capes Kronotsky and Shipunsky near Site LV 63-41-2 during the $\mathrm{B} / \mathrm{A}$. This hydrographic condition is supported by relatively high $\mathrm{C}_{37: 4}$ contents measured from our core (Fig. 3c). All instances indicate that the surface hydrographies in the Bering Sea and the subarctic NW
Pacific are highly spatially variable due to the interactions of meltwater from mountain glaciers and local currents.

\section{The YD ( 12.8-11.8 ka)}

Alkenone proxies indicate a cooling in most of the subarctic NW Pacific (the Bering Sea, Okhotsk Sea, and the offshore of the northern Kamchatka) during the YD (Fig. 4). Sea ice cover would be extended to the western Bering Sea and likely further to the southern offshore of the Kamchatka during the YD (Méheust et al. 2016). Our alkenone SST record, again, as during the last glacial and HE 1, shows apparent "warming" during the YD. A similar warming condition revealed from the foraminifer and $\mathrm{Mg} / \mathrm{Ca}$ temperatures at the center of the NPSG showed a relatively well-stratified surface ocean during the YD (MD012416; Gebhardt et al. 2008). We attribute the YD "warming" to the similar mechanisms in which the changes of growing seasons of coccolithophores, the effects of fresh/meltwater barrier-layer, and possibly, more dynamic interactions between the AS and NPSG would have jointly played roles. This interpretation is consistent with high magnetic susceptibility and high IRD coarse fraction that are indicative of the flooding of more meltwater inferred from the same core during the interval of the YD (Gorbarenko et al. 2017). The more stratified surface water hydrography during the YD would limit the vertical transfer of nutrients and, therefore, alkenone productions as well (Fig. 2b)

\section{The Holocene}

Alkenone proxy records compiled here indicate an early Holocene (approximately $9 \mathrm{ka}$ ) SST maximum near approximately the Bering Sea (SO 201-2-77KL, $-85 \mathrm{KL}$; Fig. 4). The timing of the SST maximum is close to the local solar insolation maximum (at $65^{\circ} \mathrm{N}$; Laskar et al. 2004). While Bering Sea SSTs have been decreasing gradually since the early Holocene, a rise in our alkenone SSTs $\left(\sim 7.5\right.$ to $\left.10{ }^{\circ} \mathrm{C}\right)$ is from the early Holocene toward the present (Fig. 4). This is in accordance with no $\mathrm{IP}_{25}$ biomarkers and high alkenone SSTs off Kamchatka (Max et al. 2012), revealing a long-term sea ice retreat with ice-free conditions at our site in comparison with that prior to the Holocene. However, at sites near the southern offshore of the Kamchatka (LV 63-41-2) and the Okhotsk Sea (MD012412), the early Holocene is characterized by a cooling rather than warming (Fig. 4). The early Holocene cooling observed here is not disentangled from the well-known, shorted-lived $8.2 \mathrm{ka}$ cooling (Cheng et al. 2009; Liu et al. 2013) due to age model uncertainties. The early Holocene cooling well-expressed in the offshore Kamchatka and Okhotsk Sea is likely attributed to the strengthened AS cold waters associated 
with increased meltwaters and icebergs from the northeastern Pacific and meltwater flood at the offshore southern Kamchatka, with the Bering Sea not affected. Those cold, nutrient-rich AS waters may also contribute to phytoplankton blooms with higher coccolithophores and diatom abundances off Kamchatka through the end of the YD to the early Holocene (Méheust et al. 2016) (Fig. 2b). The gradual transformation into "warming" with low productivity since the early Holocene in the offshore Kamchatka and Okhotsk Sea is probably driven and complicated by various mechanisms such as a weakened or northward movement of the Siberia High, with increased Asian summer monsoon precipitation, and these climatic factors, along with possibly more moisture brought by the oligotrophic Kuroshio (Harada et al. 2004), may all contribute the late Holocene warming and low alkenone productivity, as we observed in this study.

\section{Conclusions}

In this study, we have documented the last glacial organic geochemical proxy changes (including $\mathrm{U}^{\mathrm{k}^{\prime}}{ }_{37}-\mathrm{SST}$, $\mathrm{C}_{37}$ alkenone concentration, and $\mathrm{C}_{37: 4}$ freshwater index) from the core LV 63-41-2 at the southern offshore of the eastern Kamchatka. Our studies provide new insights into the deglacial surface hydrographic variability that has been governed by both local to global climatic and oceanographic processes in the Bering Sea and the subarctic NW Pacific. The alkenone proxies have limitations in estimating SSTs for areas such as of this study that are characterized by strong shifting of timing and duration of warm seasons in which coccolithophores prefer to live, various inputs of larger amounts of fresh/meltwaters that cause changes in surface water stratifications, and complex ocean current patterns that result in coastal downwelling or upwelling. We conclude that the paleoceanographic reconstruction of the Bering Sea and subarctic NW Pacific is complicated by the drastic local changes of seasonality that affects the productivity of proxy organisms, the extents of sea ice and mountain glaciers with varied amount of meltwater inputs, and the dynamics of open ocean gyres that changes. All of the above local to regional non-thermal environmental influences would bias our alkenone SST estimates for global climate variability related to insolation, ice volume, monsoons, the Kuroshio, and basin-scale overturning circulations.

\footnotetext{
Abbreviations

AMS: Accelerator mass spectrometric; ANSC: Aleutian North Slope Current; AS: Alaskan Stream; B/A: Bølling-Allerød; CIS: Cordilleran Ice Sheet; EKC: East Kamchatka Current; GC: Gas chromatograph; GOA: Gulf of Alaska; HE: Heinrich event; IRD: Ice-rafted debris; LGM: Last glacial maximum; NPSG: North Pacific Subarctic Gyre; NW: Northwestern; OC: Oyashio Current; SST: Sea surface temperature; YD: Younger Dryas
}

\section{Acknowledgements}

This study was supported by grants from the Joint Projects of MOST (Ministry of Science and Technology)/FEBRAS (Far East Branch of Russian Academy of Sciences) to MTC. The authors would like to thank the crew on the RN Akademik M.A. Lavrentyev during the Joint Russian-Chinese Expedition for their coring and curatorial assistance.

\begin{abstract}
Authors' contributions
Taiwan Ocean Research Institute, National Applied Research Laboratories, Kaohsiung 80143, Taiwan. Pai-Sen Yu Institute of Earth Sciences \& Center of Excellence for the Oceans \& Center of Excellence for Ocean Engineering, National Taiwan Ocean University, Keelung 20224, Taiwan. Chia-Ju Liao \& MinTe Chen Pilot National Laboratory for Marine Science and Technology, Qingdao 266061, China. Min-Te Chen, Jian-Jun Zou \& Xuefa Shi First Institute of Oceanography, State Oceanic Administration, Qingdao, China. Jian-Jun Zou \& Xuefa Shi V.I. Il'ichev Pacific Oceanological Institute, Far-Eastern Division of the Russian Academy of Sciences, Vladivostok, Russia. A. A. Bosin \& Sergey A. Gorbarenko Atmosphere and Ocean Research Institute and Department of Earth and Planetary Sciences, University of Tokyo, Japan / Institute of Biogeosciences, Japan Agency for Marine-Earth Science and Technology, Japan. Yusuke Yokoyama MTC, JZ, XS, AAB, and SAG proposed the topic, conceived, and designed the study. PSY and MTC collaborated with the corresponding author in the construction of manuscript. CJL carried out the experimental study. YY analyzed four more AMS ${ }^{14} \mathrm{C}$ dates. All authors helped in their interpretations. All authors read and approved the final manuscript.
\end{abstract}

\section{Funding}

This study was supported by grants from the Joint Projects of MOST (Ministry of Science and Technology)/FEBRAS (Far East Branch of Russian Academy of Sciences) to MTC. This work is also partly supported by the National Program on Global Change and Air-Sea Interaction (grant no. GASIGEOGE-04) and the National Natural Science Foundation of China (grant nos. 41476056 and U1606401) to JJZ.

\section{Availability of data and materials}

The datasets used and/or analyzed during the current study are available from the corresponding author on reasonable request.

\section{Competing interests}

The authors declare that they have no competing interest.

\section{Author details}

${ }^{1}$ Taiwan Ocean Research Institute, National Applied Research Laboratories, Kaohsiung 80143, Taiwan. ${ }^{2}$ Institute of Earth Sciences \& Center of Excellence for the Oceans \& Center of Excellence for Ocean Engineering, National Taiwan Ocean University, Keelung 20224, Taiwan. ${ }^{3}$ Pilot National Laboratory for Marine Science and Technology, Qingdao 266061, China. ${ }^{4}$ First Institute of Oceanography, State Oceanic Administration, Qingdao, China. ${ }^{5}$ V.I. Il'ichev Pacific Oceanological Institute, Far-Eastern Division of the Russian Academy of Sciences, Vladivostok, Russia. ${ }^{6}$ Atmosphere and Ocean Research Institute, University of Tokyo, Tokyo, Japan. ${ }^{7}$ Department of Earth and Planetary Sciences, University of Tokyo, Tokyo, Japan. ${ }^{8}$ Institute of Biogeosciences, Japan Agency for Marine-Earth Science and Technology, Yokosuka, Japan.

Received: 1 January 2020 Accepted: 22 May 2020

Published online: 04 June 2020

\section{References}

Banzon V, Smith TM, Chin TM, Liu C, Hankins W (2016) A long-term record of blended satellite and in situ sea-surface temperature for climate monitoring, modeling and environmental studies. Earth Syst Sci Data 8:165-176. https:// doi.org/10.5194/essd-8-165-2016

Barron JA, Heusser L, Herbert T, Lyle M (2003) High-resolution climatic evolution of coastal northern California during the past 16,000 years. Paleoceanogr 18(1):1020. https://doi.org/10.1029/2002PA000768

Bigg GR, Clark CD, Hughes ALC (2008) A last glacial ice sheet on the Pacific Russian coast and catastrophic change arising from coupled ice-volcanic interaction. Earth Planet Sci Lett 265(3-4):559-570 https://doi.org/10.1016/j. epsl.2007.10.052

Caissie BE, Brigham-Grette J, Lawrence KT, Herbert TD, Cook MS (2010) Last Glacial Maximum to Holocene Sea surface conditions at Umnak Plateau, 
Bering Sea, as inferred from diatom, alkenone, and stable isotope records. Paleoceanogr 25:1-16 https://doi.org/10.1029/2008PA001671

Cheng H, Fleitmann D, Edwards RL, Wang X, Cruz FW, Auler AS, Mangini A, Wang Y, Kong X, Burns SJ, Matter A (2009) Timing and structure of the 8.2. kyr B.P. event inferred from $\delta^{18} \mathrm{O}$ records of stalagmites from China, Oman, and Brazil. Geol 37(11):1007-1010. https://doi.org/10.1130/G30126A.1

CLIMAP Project Members (1981) Seasonal reconstructions of the Earth surface at the last glacial maximum. Geol Soc Amer Map and Chart Series MC-36

Conte MH, Sicre MA, Rühlemann C, Weber JC, Schulte S, Schulz-Bull D, Blanz T (2006) Global temperature calibration of the alkenone unsaturation index $\left(\mathrm{U}^{\mathrm{k}^{\prime}}{ }_{37}\right)$ in surface waters and comparison with surface sediments. Geochem Geophys Geosyst 7. https://doi.org/10.1029/2005GC001054

Davies MH, Mix AC, Stoner JS, Addison JA, Jaeger J, Finney B, Wiest J (2011) The deglacial transition on the southeastern Alaska Margin: meltwater input, sea level rise, marine productivity, and sedimentary anoxia. Paleoceanogr 26(2):118 https://doi.org/10.1029/2010PA002051

Favorite F, Dodimead AJ, Nasu K (1976) Oceanography of the subarctic Pacific region, 1960-1971. Number 33 in INPFC Bulletins, INPFC (http://www.npafc. org/new/inpfc/INPFC Bulletin/Bull No.33/Bulletin 33.pdf).

Gebhardt H, Sarnthein M, Grootes PM, Kiefer T, Kuehn H, Schmieder F, Röhl U (2008) Paleonutrient and productivity records from the subarctic North Pacific for Pleistocene glacial terminations I to V. Paleoceanogr 23(4):1-21 https://doi.org/10.1029/2007PA001513

Gong X, Lembke-Jene L, Lohmann G, Knorr G, Tiedemann R, Zou JJ, Shi XF (2019) Enhanced North Pacific deep-ocean stratification by stronger intermediate water formation during Heinrich Stadial 1. Nat Commun 10(1):656 https://doi. org/10.1038/s41467-019-08606-2

Gorbarenko S, Shi X, Zou J, Velivetskaya T, Artemova A, Liu Y, Yanchenko E, Vasilenko Y (2019) Evidence of meltwater pulses into the North Pacific over the last 20 ka due to the decay of Kamchatka Glaciers and Cordilleran Ice Sheet. Glob Planet Chang 172:33-44. https://doi.org/10.1016/j.gloplacha.2018. 09.014

Gorbarenko SA (1996) Stable isotope and lithologic evidence of late-glacial and Holocene oceanography of the northwestern Pacific and its marginal seas. Quat Res 46(3):230-250

Gorbarenko SA, Shi X, Chen MT, Malakhova GY, Bosin AA, Liu Y, Zou J (2017) Centennial to millennial climate variability in the far northwestern Pacific (off Kamchatka) and its linkage to East Asian monsoon and North Atlantic from the Last Glacial Maximum to the early Holocene. Clim Past 13:1063-1080

Harada N, Ahagon N, Sakamoto T, Uchida M, Ikehara M, Shibata Y (2006) Rapid fluctuation of alkenone temperature in the southwestern Okhotsk Sea during the past 120 ky. Glob Planet Chang 53(1-2):29-46. https://doi.org/10.1016/j. gloplacha.2006.01.010

Harada N, Ahagon N, Uchida M, Murayama M (2004) Northward and southward migrations of frontal zones during the past $40 \mathrm{kyr}$ in the Kuroshio Oyashio transition area. Geochem Geophys Geosyst 5. https://doi.org/10.1029/ 2004GC000740

Harada N, Shin KH, Murata A, Uchida M, Nakatani T (2003) Characteristics of alkenones synthesized by a bloom of Emiliania huxleyi in the Bering Sea. Geochim Cosmochim Acta 67(8):1507-1519

Hendy IL, Cosma T (2008) Vulnerability of the Cordilleran Ice Sheet to iceberg calving during late Quaternary rapid climate change events. Paleoceanogr 23:PA2101 https://doi.org/10.1029/2008PA001606

Ishiwatari R, Houtatsu M, Okada H (2001) Alkenone-sea surface temperatures in the Japan Sea over the past 36 kyr: warm temperatures at the last glacial maximum. Org Geochem 32:57-67

Katsuki K, Takahashi K (2005) Diatoms as paleoenvironmental proxies for seasonal productivity, sea ice and surface circulation in the Bering Sea during the late Quaternary. Deep-Sea Res PT II 52(16-18):2110-2130

Laskar J, Robutel P, Joutel F, Gastineau M, Correia ACM, Levrard B (2004) A long term numerical solution for the insolation quantities of the Earth. Astron Astrophys 428:261-285

Liu YH, Henderson GM, Hu CY, Mason AJ, Charnley N, Johnson KR, Xie SC (2013) Links between the East Asian monsoon and North Atlantic climate during the 8,200 year event. Nat Geosci 6(2):117-120. https:/doi.org/10.1038/ngeo1708

Locarnini RA, Mishonov AV, Antonov Jl, Boyer TP, Garcia HE (2010) World Ocean Atlas 2009, Volume 1: Temperature, in NOAA Atlas NESDIS 68. U.S. Government Printing Office, Washington, D.C.

Maier E, Zhang X, Abelmann A, Gersonde R, Mulitza S, Werner M et al (2018) North Pacific freshwater events linked to changes in glacial ocean circulation. Nature 559(7713):241-245 https://doi.org/10.1038/s41586-018-0276-y
MARGO project members (2009) Constraints on the magnitude and patterns of ocean cooling at the Last Glacial Maximum. Nat Geosci 2:127-132

Max L, Riethdorf JR, Tiedemann R, Smirnova MA, Lembke-Jene L, Fahl K, Nürnberg D, Matul AG, Mollenhauer G (2012) Sea surface temperature variability and sea-ice extent in the subarctic Northwest Pacific during the past 15,000 years. Paleoceanogr 27:PA3213. https://doi.org/10.1029/ 2012PA002292

Méheust M, Stein R, Fahl K, Gersonde R (2018) Sea-ice variability in the subarctic North Pacific and adjacent Bering Sea during the past 25 ka: new insights from $\mathbb{P}_{25}$ and $U_{37}^{k_{\prime}}$ proxy records. Arktos 4(1):8 https://doi.org/10.1007/ s41063-018-0043-1

Méheust M, Stein R, Fahl K, Max L, Riethdorf JR (2016) High-resolution IP 25 -based reconstruction of sea ice variability in the western North Pacific and Bering Sea during the past 18,000 years. Geo-Mar Lett 36(2):101-111

Meyer VD, Max L, Hefter J, Tiedemann R, Mollenhauer G (2016) Glacial-toHolocene evolution of sea surface temperature and surface circulation in the subarctic northwest Pacific and the Western Bering Sea. Paleoceanogr 31(7): 916-927 https://doi.org/10.1002/2015PA002877

Müller PJ, Kirst G, Ruhland G, Von Storch I, Rosell-Melé A (1998) Calibration of the alkenone paleotemperature index $U^{k^{\prime}} 37$ based on core-tops from the eastern South Atlantic and the global ocean $\left(60^{\circ} \mathrm{N}-60^{\circ} \mathrm{S}\right)$. Geochim Cosmochim Acta 62(10):1757-1772

North Greenland Ice Core Project members (2004) High-resolution record of Northern Hemisphere climate extending into the last interglacial period. Nature 431:147-151. https://doi.org/10.1038/nature02805

Panteleev G, Stabeno P, Luchin VA, Nechaev D, Ikeda M (2006) Summer transport estimates of the Kamchatka Current derived as a variational inverse of hydrophysical and surface drifter data. Geophys Res Lett 33:L09609. https:// doi.org/10.1029/2005GL024974

Popp BN, Prahl FG, Wallsgrove RJ, Tanimoto J (2006) Seasonal patterns if alkenone production in the subtropical oligotrophic North Pacific. Paleoceanogr 21:PA1004. https://doi.org/10.1029/2005PA001165

Prahl FG, Muehlhausen LA, Zahnle DL (1988) Further evaluation of long-chain alkenones as indicators of paleoceanographic conditions. Geochim Cosmochim Acta 52:2303-2310

Prahl FG, Wakeham SG (1987) Calibration of unsaturation patterns in long-chain ketone compositions for palaeotemperature assessment. Nature 330(6146):367-369

Riethdorf JR, Max L, Nürnberg D, Lembke-Jene L, Tiedemann R (2013) Deglacial development of (sub) sea surface temperature and salinity in the subarctic northwest Pacific: implications for upper-ocean stratification. Paleoceanogr 28(1):91-104 https://doi.org/10.1002/palo.20014

Rosell-Melé A (1998) Interhemispheric appraisal of the value of alkenone indices as temperature and salinity proxies in high-latitude locations. Paleoceanogr Paleoclimatol 13(6):694-703

Rosell-Melé A, Carter J, Eglinton G (1994) Distributions of long-chain alkenones and alkyl alkenoates in marine surface sediments from the North East Atlantic. Org Geochem 22(3-5):501-509

Schlung SA, Ravelo CA, Aiello IW, Andreasen DH, Cook MS, Drake M, Dyez KA, Guilderson TP, Lariviere JP, Stroynowski Z, Takahashi K (2013) Millennial-scale climate change and intermediate water circulation in the Bering Sea from 90 ka: a high-resolution record from IODP Site U1340. Paleoceanogr 28:54-67. https://doi.org/10.1029/2012PA002365

Seki O, Ikehara M, Kawamura K, Nakatsuka T, Ohnishi K, Wakatsuchi M, Narita H, Sakamoto T (2004a) Reconstruction of paleoproductivity in the Sea of Okhotsk over the last 30 kyr. Paleoceanogr 19(1). https://doi.org/10.1029/2002PA000808

Seki O, Kawamura K, Ikehara M, Nakatsuka T, Oba T (2004b) Variation of alkenone sea surface temperature in the Sea of Okhotsk over the last 85 kyrs. Org Geochem 35(3):347-354

Seki O, Nakatsuka T, Kawamura K, Saitoh SI, Wakatsuchi M (2007) Time-series sediment trap record of alkenones from the western Sea of Okhotsk. Mar Chem 104(3-4):253-265. https://doi.org/10.1016/j.marchem.2006.12.002

Seki O, Kawamura K, Sakamoto T, Ikehara M, Nakatsuka T, Wakatsuchi M (2005) Decreased surface salinity in the Sea Okhotsk during the last glacial period estimated from alkenones. Geophys Res Lett 32(8). https://doi.org/10.1029/ 2004GL02217

Sikes EL, Sicre MA (2002) Relationship of the tetra-unsaturated $C_{37}$ alkenone to salinity and temperature: implications for paleoproxy applications. Geochem Geophys Geosyst 3(11):1063. https://doi.org/10.1029/2002GC000345

Smirnova MA, Kazarina GK, Matul AG, Max L (2015) Diatom evidence for paleoclimate changes in the northwestern Pacific during the last 20000 years. Mar Geol 55(3):425-431 https://doi.org/10.1134/S0001437015030157 
Stabeno PJ, Kachel DG, Kachel NB, Sullivan ME (2005) Observations from moorings in the Aleutian Passes: temperature, salinity and transport. Fish Oceanogr 14:9-54. https://doi.org/10.1111/j.1365-2419.2005.00362.x

Stabeno PJ, Schumacher JD, Ohtani K (1999) The physical oceanography of the Bering Sea. In: Loughlin TR, Ohtani K (eds) Dynamics of the Bering Sea: a summary of physical, chemical, and biological characteristics, and a synopsis of research on the Bering Sea, vol 99 of Alaska Sea Grant College Program report. University of Alaska Sea Grant, pp 1-28

Takahashi K, Fujitani N, Yanada M (2002) Long term monitoring of particle fluxes in the Bering Sea and the central subarctic Pacific Ocean, 1990-2000. Prog Oceanogr 55(1-2):95-112. https://doi.org/10.1016/S0079-6611(02) 00072-1

Taylor MA, Hendy IL, Pak DK (2014) Deglacial ocean warming and marine margin retreat of the Cordilleran Ice Sheet in the North Pacific Ocean. Earth Planet Sci Lett 403:89-98 https://doi.org/10.1016/j.epsl.2014.06.026

Ternois Y, Kawamura K, Ohkouchi N, Keigwin L (2000) Alkenone sea surface temperature in the Okhotsk Sea for the last 15 kyr. Geochem J 34(4):283-293

Wang XF, Auler AS, Edwards RL, Cheng H, Cristalll PS, Smart PL, Richards DA, Shen CC (2004) Wet periods in northeastern Brazil over the past $210 \mathrm{kyr}$ linked to distant climate anomalies. Nature 432:740-743

Woodgate RA, Aagaard K, Weingartner TJ (2005) Monthly temperature, salinity, and transport variability of the Bering Strait through flow. Geophys Res Lett 32(4):L04601. https://doi.org/10.1029/2004GL021880

Zhang J, Woodgate R, Moritz R (2010) Sea ice response to atmospheric and oceanic forcing in the Bering Sea. J Phys Oceanogr 40(8):1729-1747

\section{Publisher's Note}

Springer Nature remains neutral with regard to jurisdictional claims in published maps and institutional affiliations.

\section{Submit your manuscript to a SpringerOpen ${ }^{\circ}$ journal and benefit from:}

- Convenient online submission

- Rigorous peer review

- Open access: articles freely available online

- High visibility within the field

- Retaining the copyright to your article

Submit your next manuscript at $\boldsymbol{\nabla}$ springeropen.com 